\title{
The Composition, Distribution and Abundance of Fish Species According to the Effects of Water Physicochemical Parameters in the Livoq Lake, Kosovo
}

\author{
Linda Grapci-Kotori', Bekim Ibrahimi' ${ }^{1}$, Astrit Bilalli² ${ }^{*}$, Halil Ibrahimi', Milaim Musliu² \\ 1 University of Prishtina, Faculty of Natural and Mathematical Sciences, Department of Biology, Kosovo \\ 2 University of Peja "Haxhi Zeka", Faculty of Agribusiness, Pejë, Kosovo \\ * Corresponding author's e-mail: astritbilalli@yahoo.com
}

\begin{abstract}
In this study, the results of fish composition, distribution and abundance are presented according to the effects of water physicochemical parameters from the Livoq Lake in the eastern part of Kosovo. The fish specimens were sampled in six sampling stations in 2018 by using a variety of methods, including electro-fishing devices, fishing rod and cast nets. The measured physicochemical parameters included: water temperature, dissolved oxygen, saturation of dissolved oxygen, $\mathrm{pH}$, conductivity, total dissolved solids. In total, 320 fish specimens were collected, belonging to 10 species of the following 5 families: Cyprinidae, Silurideae, Esocideae, Percideae and Centrarhideae. The most species rich family is Cyprinidae with 6 species in total: Cyprinus caprio Linnaeus, 1758, Rutilus rutilus Linnaeus, 1758, Carassius carassius Linnaeus, 1758, Squalius cephalus Linnaeus, 1758, Leucaspius delineatus Linnaeeus, 1758 and Alburnus alburnus Linnaeus, 1758. Four other families are represented by one species each: Silurideae with Siluris glanis Linnaeus, 1758, Esocidea with Esox lucius Linnaeus, 1758, Percideae with Perca fluviatilis Linnaeus, 1758 and Centrarhideae with Lepomis gibosus Linnaeus, 1758. The knowledge on fish fauna in Kosovo is still very fragmentary, and this investigation contributes to determining the qualitative composition and abundance features based on the water physicochemical parameters in this part of the Balkan Peninsula.
\end{abstract}

Keywords: Livoq Lake, fish distribution, fish composition, abundance, water quality.

\section{INTRODUCTION}

Freshwater fishes are one of the most highly threatened species groups in Europe with approximately $37 \%$ of species threatened (Freyhof and Brooks, 2011). Documenting diversity, abundance and threatening factors is thus an important step towards the conservation and protection of fish species. Despite unfavorable trends in the management of freshwater ecosystems in Kosovo, directly impacting the fish fauna, many alien species were intentionally or unintentionally introduced in the past decades, thus increasing the threat towards the native fish species (Gashi et al., 2016). The physicochemical parameters of water were also analyzed in different water bodies in Kosovo (Musliu et al., 2018)
It is well-known that the distribution of fish species in lake depends on several abiotic and biotic factors (Kadye et al., 2008). Among the biotic factors, predation and competition play a main role on fish population. Moreover, the abiotic factors such as water temperature and oxygen are two parameters that have influence on the fish distribution and population survival in the lake. High temperatures influence on high physiological demands apart from reducing the dissolved oxygen level from the water body. This process indicates the importance of the oxygen and its relationship with water temperature (Jackson et al., 2011).

Freshwater ecosystems in the Republic of Kosovo belong to three water basins: the Black Sea, the Adriatic Sea and the Aegean Sea. The fish fauna in Kosovo is still moderately investigated 
with many areas still completely unknown in regards to the diversity and abundance of fish species. The previous ichthyofaunal investigations in Kosovo were more focused on the rivers belonging to the Adriatic Sea basin, while the other two basins have only been investigated occasionally (e.g. Grapci-Kotori et al., 2010; Maxhuni et al., 2010).

The Livoq Lake is a small artificial lake in eastern Kosovo, located on the eastern side of Gjilan and bordering the Gollak Mountains to its west. It is located in $42^{\circ} 27^{\prime} 50^{\prime \prime} \mathrm{N}$ latitude and $21^{\circ} 24^{\prime} 55^{\prime \prime} \mathrm{E}$ longitude coordinates, above $565 \mathrm{~m}$ of see level. The lake is fed by a small tributary of the South Morava River. It is the second largest lake in the east of Kosovo. The maximum length of the lake is $700 \mathrm{~m}$ with maximum width of $200 \mathrm{~m}$ and a total surface area $0.08 \mathrm{~km}^{2}$.

This study is a first attempt to examine the current state of fish composition, distribution and abundance and relationship between fish fauna and physicochemical parameters in the artificial Livoq Lake which belongs to Black See basin.

\section{MATERIAL AND METHODS}

The study was carried out during the period of January-June 2018. The sampling stations were divided in two groups: 3 sites are located along the littoral zone (L1, L2 and L3) and another three were from limnetic zone of lake (L1.1, L2.2 and L3.3) with the distance from $34.56 \mathrm{~m}$ up to $72.13 \mathrm{~m}$ from the shore (Fig. 1).

The selection of 6 sampling stations in Livoq Lake was done based on the habitat structure, water depth and velocity, size and structure of the substratum, and, above all, the information gained from fishermen about the most suitable zones for fish sampling. The first station (L1) is located at the beginning of the lake from the main road Prishtina-Gjilan. The second station L1.1 is located $72.13 \mathrm{~m}$ from the shore at the middle part of lake. The third station L2 is located $241 \mathrm{~m}$ from the L1 along the lake shore. The fourth station L 2,2 is located at the middle part of lake, $34.56 \mathrm{~m}$ from the shore. The fifth station L3 is located near the dam, $150 \mathrm{~m}$ from L2. The sixth station L3.3 is located at the middle of the lake, $60 \mathrm{~m}$ from the shore.

In order to capture fish species in the littoral areas we have used fishing rod for $2 \mathrm{~h}$, and in the limnetic area, net was cast two hours before sunset. The electrofishing device was used only twice in the littoral area. In order to explore the fish fauna of the Livoqi Lake, monthly samples were taken during January-June 2018. We did not sample in April because of the breeding time. Sampling was conducted simultaneously at the littoral and limnetic regions of lakes. The sampling

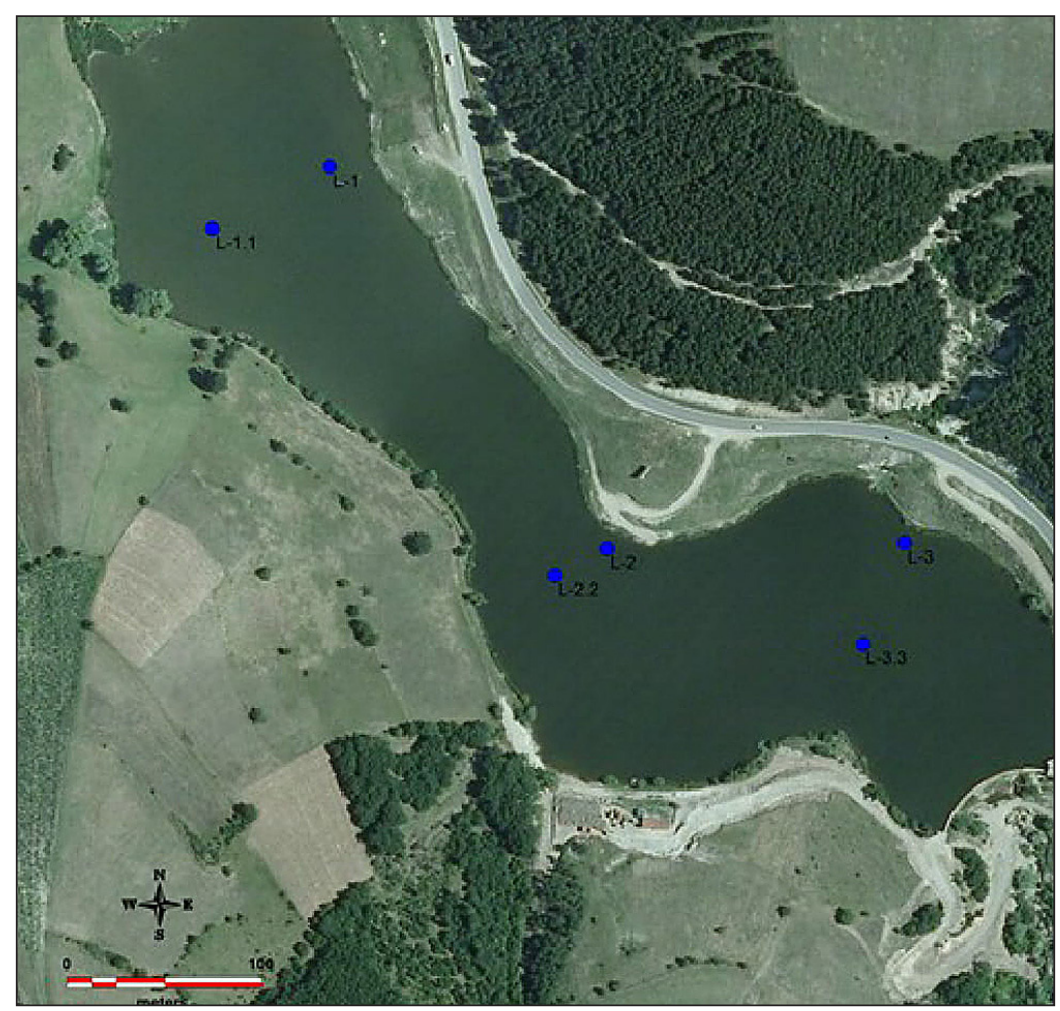

Figure 1. The location of the six sampling stations at the Livoq Lake 
program and strategy were adopted according to the lake type and covering the seasonal variation of fish composition and also having in mind the breeding season for most of the fishes found in the lake. The fish were measured and identified by using the keys according to Kottelat and Freyhof (2007), Simonović (2001), Rakaj (1995) and Vuković and Ivanović (1971). All fish species were identified up to the species level. The fish community structure was analyzed in terms of total number of species (s), Shannon Wiener diversity index and the Margalef's index. The statistical analysis was performed using Excel and the ComEcoPac software.

The physiochemical parameters such as water temperature, dissolved oxygen, saturation of dissolved oxygen, $\mathrm{pH}$, conductivity and total dissolved solids were measured with Multi-Parameter Water Quality Portable Meter HI-9828 Hanna.

\section{RESULTS}

During this investigation, we found 320 fish specimens belonging to 10 species and 5 families
(Table 1). The highest number of species belongs to the family Cyprinidae (6), while each of the other 4 families is represented by a single species.

The highest number of fish species is found in L1, L1.1, L2 and L3 (per 7 species) whereas in the remaining two sampling stations (L2.2 and L3.3) were found 4 species each. The highest number of specimens was caught at station L3 (83), while the lowest - at station L2.2 (28 specimens). The Carassius carassius species is found in all sampling stations. The family Percidae with P.fluviatilis is missing in stations L2.2 and L 3.3. The representatives of other two families $S$. glanis (Siluridae) and E.lucius (Esocidae) are found only in the stations located in the middle section of the lake (L1.1, L2.2, L3.3) where fishing was done by using nets. Lepomis gibbosus, representing the family Centrarhidae, is the only alien species that was present at three investigated stations (L1. L2. and L3) of Livoqi Lake where fishing was done with electrofishing device and by fish hook.

According to the Jaccard index of similarity, it is shown that the stations L1, L2 and L3 are similar between each other regarding fish species composition. The lowest values of the similarity

Table 1. Composition of fish fauna in 6 sampling stations in Livoqi Lake

\begin{tabular}{|c|c|c|c|c|c|c|c|c|c|c|}
\hline \multirow{2}{*}{ No. } & & \multirow{2}{*}{$\begin{array}{l}\text { Recorded } \\
\text { previously in } \\
\text { Kosovo } \\
\end{array}$} & \multirow{2}{*}{ Native/introd. } & \multirow{2}{*}{ L1 } & \multirow{2}{*}{ L1.1 } & \multirow{2}{*}{ L 2} & \multirow{2}{*}{ L2.2 } & \multirow{2}{*}{ L 3} & \multirow{2}{*}{ L3.3 } & \multirow{2}{*}{$\begin{array}{l}\text { IUCN } \\
\text { status }\end{array}$} \\
\hline & CYPRINIDEA & & & & & & & & & \\
\hline 1 & $\begin{array}{l}\text { Cyprinus caprio } \\
\text { Linnaeus, } 1758\end{array}$ & + & Introduced & - & + & - & + & - & + & VU \\
\hline 2 & $\begin{array}{l}\text { Rutilus rutilus } \\
\text { Linnaeus, } 1758\end{array}$ & + & Native & + & + & + & - & + & - & LC \\
\hline 3 & $\begin{array}{l}\text { Carassius carassius } \\
\text { Linnaeus, } 1758\end{array}$ & + & Native & + & + & + & + & + & + & LC \\
\hline 4 & $\begin{array}{l}\text { Squalius cephalus } \\
\text { Linnaeus, } 1758\end{array}$ & + & Native & + & + & + & - & + & - & LC \\
\hline 5 & $\begin{array}{l}\text { Leucaspius delineatus } \\
\text { Linnaeeus, } 1758\end{array}$ & + & Introduced & + & - & + & - & + & - & LC \\
\hline \multirow[t]{2}{*}{6} & $\begin{array}{l}\text { Alburnus alburnus } \\
\text { Linnaeus, } 1758\end{array}$ & + & Introduced & + & - & + & - & + & - & LC \\
\hline & PERCIDEAE & & & & & & & & & \\
\hline \multirow[t]{2}{*}{7} & $\begin{array}{l}\text { Perca fluviatilis } \\
\text { Linnaeus, } 1758\end{array}$ & + & Introduced & + & + & + & - & + & - & LC \\
\hline & ESOCIDEAE & & & & & & & & & \\
\hline \multirow[t]{2}{*}{8} & $\begin{array}{l}\text { Esox lucius } \\
\text { Linnaeus, } 1758\end{array}$ & + & Introduced & - & + & - & + & - & + & LC \\
\hline & SILURIDEAE & & & & & & - & & - & \\
\hline \multirow[t]{2}{*}{9} & $\begin{array}{l}\text { Siluris glanis } \\
\text { Linnaeus, } 1758\end{array}$ & + & Introduced & - & + & - & + & - & + & LC \\
\hline & CENTRARHIDAE & & & & & & & & & \\
\hline 10 & $\begin{array}{l}\text { Lepomis gibbosus } \\
\text { Linnaeus, } 1758\end{array}$ & + & Alien & + & - & + & - & + & - & LC \\
\hline
\end{tabular}


coefficient were found between stations L1.1, L2.2 and L3.3.

The highest value of Menhinick's index of diversity was found at station L2, while the lowest value was found at station L3.3. The ShannonWiener index reaches the highest value at station L1 while the lowest value was found at station L3.3 (Table 2).

The highest number of specimens in the litoral area was sampled in June (65 in total), while during the other three months, the number of the caught specimens was almost similar. In this area the highest number of specimens belongs to the Leucaspius delineatus species (41 in total) and the lowest number to Lepomis gibbosus (14). The rest of the species were sampled with almost similar number of individuals. The highest number of specimens in the limnetic area was sampled in June as well (44 in total) while in the remaining three other months the number of the caught specimens was almost similar. In this area the highest number of specimens belongs to the Cyprinuys caprio species (50 in total) which is also the highest number of specimens caught during the all sampling period in all sampling stations per species. The lowest number of specimens in limnetic area was sampled for Rutilus rutilus species (only 5). Low number of specimens in this area was sampled for Squalius cephalus as well (8 in total).

The main average values of physicochemical parameters of water recorded according to the investigation time are given in Table 5.

The average of temperature in Livoqi Lake varied from $16.1-16.9^{\circ} \mathrm{C}$, values of DO range from $5.3-6.99 \mathrm{mg} / \mathrm{l}$, saturated dissolved oxygen recorded was between 71.6-94.4\%, values of $\mathrm{pH}$ ranging from 8.18-8.44, conductivity recorded was between $556-596 \mu \mathrm{S} / \mathrm{cm}$ and the TDS was between $10.5-14.2 \mathrm{mg} / \mathrm{l}$.

\section{DISCUSSION}

The distribution and composition of species in each habitat is closely related to various factors such as food availability, breeding sites, depth, topography and water chemistry (Ali et al., 1988). This was noted in our investigation as well. The results of our investigation show that such species as Siluris glanis, Cyprinus caprio and Esox lucius are found only in the sites with deep water, while the Leucaspius delineates and Alburnus alburnus species are found only along the lake shore. The

Table 2. Number of species, number of specimens, Shannon-Wiener diversity index and values of Menhinick's diversity index in 6 investigated stations of Livoqi Lake

\begin{tabular}{|c|c|c|c|c|}
\hline Sampling station & Number of species (S) & $\begin{array}{c}\text { Number of specimens } \\
(\mathrm{N})\end{array}$ & $\begin{array}{c}\text { Shannon-Wiener } \\
\text { diversity index }\end{array}$ & $\begin{array}{c}\text { Menhinick's diversity } \\
\text { index }\end{array}$ \\
\hline L1 & 7 & 50 & 2.75 & 0.98 \\
\hline L1.1 & 7 & 82 & 2.52 & 0.77 \\
\hline L2 & 7 & 46 & 2.71 & 1.03 \\
\hline L2.2 & 4 & 28 & 1.92 & 0.75 \\
\hline L3 & 7 & 83 & 2.64 & 0.76 \\
\hline L3.3 & 4 & 31 & 1.70 & 0.71 \\
\hline
\end{tabular}

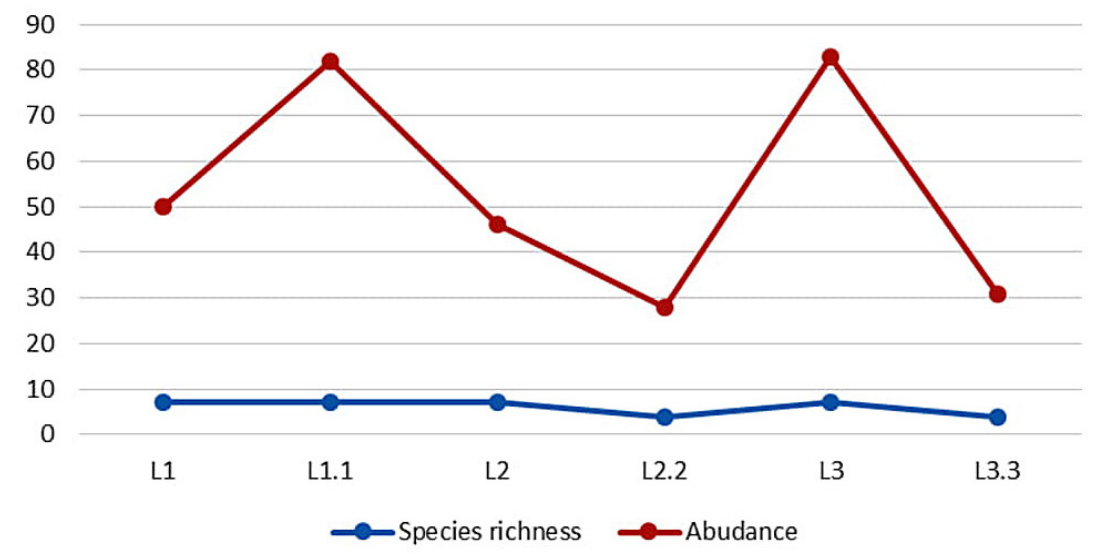

Figure 2. Species richness and abundance for six sampling stations 
Cyprinus carpio has low correlation with dissolved oxygen and water temperature (Akin et al. 2005). These results concur with our findings in this study.

Two other species, Rutilus rutilus and Squalius cephalus, are more abundant and they are found both in the localities with deep water and along the lake shore. We noted that the fish species which are widespread during this investigation are those that are highly adaptable to adverse environmental factors such as variation of water physicochemical parameters, water pollution and habitat degradation.

On the basis of the conversations with local fishermen, we can conclude that the autochthonous species for this area are Rutilus rutilus, Squalius cephalus and Carassius carassius while all other species are apparently allochthonous species, although there has been no previous investigation in this area to scientifically back up these claims.

The interesting finding during this investigation is the presence of the alien species Lepomis gibbosus, Linnaeus (1758). This species was reported for the first time from Kosovo (Gashi et al., 2016) at Badovc Lake. Apparently, the species is more widespread in Kosovo than previously thought. It is well-known that the presence, increase in abundance or the area of occupation of invasive species may be indicative of environmental degradation (Kennard et al., 2005). The impact of this species on the populations of local autochthonous fish species is still not known. In recent years, the Lepomis gibossus spread rapidly into the inland water of some of the Balkan countries (Uzunova \& Zlatanova 2007, Uzunova et al. 2008). On the basis of the previous investigations in Kosovo Rivers such as Drini i Bardhe River (Grapci-Kotori et al. 2006), Drenica River (Maxhuni et al., 2009) this species has not been found so far.

With regard to the IUCN criteria, most of the listed species are in the category of Least Concern and only one is in the category of vulnerable species (Cyprinus carpio). This species is quiet abundant; however, due to the hybridization with introduced species in Kosovo is quiet uncertain to speak precisely for pure populations of this species. It is reported as abundant in medium and lower reaches of rivers as well as lakes in Kosovo (Gashi et al., 2016).

The reasons for the variation between the littoral and limnetic areas during this investigation are ascribed to the large volume of water during investigation time, the available fish were dispersed over a wider area, and fishing became more difficult. Fishermen's catches improved greatly

Table 3. Species distribution and number of specimens during the January-June sampling period in the littoral area of the Livoq Lake

\begin{tabular}{|l|c|c|c|c|c|c|c|c|c|c|c|c|c|c|c|c|c|}
\hline Localities & \multicolumn{4}{|c|}{ L1 } & \multicolumn{4}{|c|}{ L2 } & \multicolumn{4}{|c|}{ L3 } & \multicolumn{5}{|c|}{ Total } \\
\hline Species/months & $\mathrm{J}$ & $\mathrm{F}$ & $\mathrm{M}$ & $\mathrm{J}$ & $\mathrm{J}$ & $\mathrm{F}$ & $\mathrm{M}$ & $\mathrm{J}$ & $\mathrm{J}$ & $\mathrm{F}$ & $\mathrm{M}$ & $\mathrm{J}$ & $\mathrm{J}$ & $\mathbf{F}$ & M & J & Total \\
\hline Rutilus rutilus & 2 & 2 & 1 & 2 & 1 & 2 & 1 & 1 & 3 & 2 & 2 & 3 & $\mathbf{6}$ & $\mathbf{6}$ & $\mathbf{4}$ & $\mathbf{6}$ & $\mathbf{2 2}$ \\
\hline Carassius carassius & 3 & 1 & 4 & 3 & 0 & 2 & 1 & 2 & 0 & 3 & 0 & 3 & $\mathbf{3}$ & $\mathbf{6}$ & $\mathbf{5}$ & $\mathbf{8}$ & $\mathbf{2 2}$ \\
\hline Squalius cephalus & 1 & 0 & 3 & 2 & 2 & 1 & 2 & 2 & 0 & 5 & 3 & 7 & $\mathbf{3}$ & $\mathbf{6}$ & $\mathbf{8}$ & $\mathbf{1 1}$ & $\mathbf{2 8}$ \\
\hline Leucaspius delineatus & 2 & 1 & 2 & 4 & 3 & 3 & 2 & 3 & 5 & 6 & 5 & 5 & $\mathbf{1 0}$ & $\mathbf{1 0}$ & $\mathbf{9}$ & $\mathbf{1 2}$ & $\mathbf{4 1}$ \\
\hline Alburnus alburnus & 3 & 1 & 0 & 1 & 1 & 2 & 2 & 3 & 2 & 5 & 0 & 5 & $\mathbf{6}$ & $\mathbf{8}$ & $\mathbf{2}$ & $\mathbf{9}$ & $\mathbf{2 5}$ \\
\hline Perca fluviatilis & 0 & 0 & 1 & 1 & 1 & 0 & 0 & 4 & 2 & 0 & 3 & 10 & $\mathbf{3}$ & $\mathbf{0}$ & $\mathbf{4}$ & $\mathbf{1 5}$ & $\mathbf{2 2}$ \\
\hline Lepomis gibbosus & 2 & 1 & 2 & 2 & 1 & 1 & 0 & 1 & 1 & 1 & 1 & 1 & $\mathbf{4}$ & $\mathbf{3}$ & $\mathbf{3}$ & $\mathbf{4}$ & $\mathbf{1 4}$ \\
\hline Total & $\mathbf{1 3}$ & $\mathbf{6}$ & $\mathbf{1 3}$ & $\mathbf{1 5}$ & $\mathbf{9}$ & $\mathbf{1 1}$ & $\mathbf{8}$ & $\mathbf{1 6}$ & $\mathbf{1 3}$ & $\mathbf{2 2}$ & $\mathbf{1 4}$ & $\mathbf{3 4}$ & $\mathbf{3 5}$ & $\mathbf{3 9}$ & $\mathbf{3 5}$ & $\mathbf{6 5}$ & $\mathbf{1 7 4}$ \\
\hline
\end{tabular}

Table 4. Species distribution and number of specimens during the January-June sampling period in the limnetic area of the Livoq Lake

\begin{tabular}{|l|c|c|c|c|c|c|c|c|c|c|c|c|c|c|c|c|c|c|}
\hline Localities & \multicolumn{4}{|c|}{ L1.1 } & \multicolumn{4}{|c|}{ L2.2 } & \multicolumn{4}{|c|}{ L3.3 } & \multicolumn{4}{c|}{ Total } \\
\hline Species/months & $\mathrm{J}$ & $\mathrm{F}$ & $\mathrm{M}$ & $\mathrm{J}$ & $\mathrm{J}$ & $\mathrm{F}$ & $\mathrm{M}$ & $\mathrm{J}$ & $\mathrm{J}$ & $\mathrm{F}$ & $\mathrm{M}$ & $\mathrm{J}$ & $\mathrm{J}$ & $\mathrm{F}$ & $\mathbf{M}$ & $\mathrm{J}$ & Total \\
\hline Cyprinus carpio & 7 & 3 & 5 & 14 & 3 & 2 & 2 & 2 & 4 & 5 & 2 & 9 & $\mathbf{1 4}$ & $\mathbf{1 0}$ & $\mathbf{9}$ & $\mathbf{1 7}$ & $\mathbf{5 8}$ \\
\hline Rutilus rutilus & 0 & 1 & 2 & 2 & 0 & 0 & 0 & 0 & 0 & 0 & 0 & 0 & $\mathbf{0}$ & $\mathbf{1}$ & $\mathbf{2}$ & $\mathbf{2}$ & $\mathbf{5}$ \\
\hline Carassius carassius & 3 & 5 & 5 & 7 & 2 & 2 & 4 & 1 & 2 & 2 & 2 & 2 & $\mathbf{7}$ & $\mathbf{9}$ & $\mathbf{1 1}$ & $\mathbf{1 0}$ & $\mathbf{3 7}$ \\
\hline Squalius cephalus & 2 & 2 & 2 & 2 & 0 & 0 & 0 & 0 & 0 & 0 & 0 & 0 & $\mathbf{2}$ & $\mathbf{2}$ & $\mathbf{2}$ & $\mathbf{2}$ & $\mathbf{8}$ \\
\hline Esox lucius & 2 & 2 & 1 & 4 & 1 & 0 & 2 & 3 & 2 & 0 & 0 & 2 & $\mathbf{5}$ & $\mathbf{2}$ & $\mathbf{3}$ & $\mathbf{9}$ & $\mathbf{1 9}$ \\
\hline Silurus glanis & 3 & 5 & 2 & 2 & 0 & 2 & 2 & 0 & 0 & 0 & 1 & 2 & $\mathbf{3}$ & $\mathbf{7}$ & $\mathbf{5}$ & $\mathbf{4}$ & $\mathbf{1 9}$ \\
\hline Total & $\mathbf{1 7}$ & $\mathbf{1 8}$ & $\mathbf{1 7}$ & $\mathbf{3 1}$ & $\mathbf{6}$ & $\mathbf{6}$ & $\mathbf{1 0}$ & $\mathbf{6}$ & $\mathbf{8}$ & $\mathbf{7}$ & $\mathbf{5}$ & $\mathbf{1 1}$ & $\mathbf{3 1}$ & $\mathbf{3 1}$ & $\mathbf{3 2}$ & $\mathbf{4 4}$ & $\mathbf{1 4 6}$ \\
\hline
\end{tabular}


Table 5. Average values of water physicochemical parameters during investigation time January-June 2018

\begin{tabular}{|c|c|c|c|c|c|c|c|c|c|}
\hline \multirow{2}{*}{ Nr. } & \multirow{2}{*}{ Parameters } & \multirow{2}{*}{ Symbol } & \multirow{2}{*}{ Units } & \multicolumn{6}{|c|}{ Sampling stations } \\
\hline & & & & L1 & L1.1 & L2 & L2.2 & L3 & L3.3 \\
\hline 1 & Water temperature & $\mathrm{T}$ & $\mathrm{C}^{0}$ & 16.9 & 16.5 & 16.7 & 16.4 & 16.3 & 16.1 \\
\hline 2 & Dissolved oxygen & $\mathrm{DO}$ & $\mathrm{mg} / \mathrm{l}$ & 5.3 & 5.5 & 6.99 & 6.84 & 6.26 & 6.52 \\
\hline 3 & $\begin{array}{l}\text { Saturated dissolve } \\
\text { oxygen }\end{array}$ & Do & $\%$ & 71.6 & 74.2 & 94.4 & 92.3 & 84.5 & 88.1 \\
\hline 4 & $\mathrm{pH}$ value & $\mathrm{pH}$ & $0-14$ & 8.43 & 8.40 & 8.44 & 8.35 & 8.18 & 8.26 \\
\hline 5 & Conductivity & Con & $\mu S / \mathrm{cm}$ & 583 & 596 & 556 & 586 & 568 & 578 \\
\hline 6 & Total dissolved solids & TDS & $\mathrm{mg} / \mathrm{l}$ & 12 & 10.5 & 11.8 & 10.5 & 14.2 & 13.9 \\
\hline
\end{tabular}

during fishing in the littoral zone especially in month of June due to the migration of deep water fishes away from the deep waters to the upper waters during this period. The high abundance in June is also in correlation with the habitat requirements of Cyprinidae family, which is the family with the largest number of species. This species of this family are known to be more active and abundant in the months with higher temperature. This is in correlation with the findings in Prespa Lake, Northwestern Greece (Crivelli et al., 1997). However, several operational factors such as mesh size, net length, set time factors are well known to drive this temporal variability suggesting that certain species become more or less catchable by cast nets in the course of the year (Grant et al., 2004; Olin et al., 2009) (Jensen, 1986; Minns and Hurley, 1988).

\section{CONCLUSION}

There is no great difference amongst the investigated localities regarding the values of diversity indices. The reason is that the distance between localities is not so great. In general, it is noted that all localities of the littoral area are characterized with higher values of diversity indices compared to the localities located in the littoral area. The main reason for this is that the waters in the littoral zone are more shallow and thus warmer than the rest of the localities. Thus, this area is more favorable for most of the species found during this investigation.

The knowledge on the fish fauna in Kosovo is still very fragmentary, and this investigation constitutes a relevant contribution. This makes further ichthyofaunal studies in Kosovo inevitable in order to determine the qualitative composition and main threats, as well as the consequent procedures and measures for protection.

\section{REFERENCES}

1. Akin S., Buhan E., Winemiller K.O. and Yilmaz H., 2005. Fish assemblage structure of Köyceğiz Lagoon-Estuary, Turkey: Spatial and temporal distribution patterns in relation to environmental variation. Estuarine Coastal and Shelf Science, 64, 671-684.

2. Ali A., Kethergany M.S., Masor M., Batharuddin M.H.M. 1988. Fish population distribution in Perak River: A comparative study, Proc 11 Annual Seminar of Malaysian Society of Marine Sciences, $16 \mathrm{pp}$.

3. Crivelli A.J., Catsadorakis G., Mallakov M., Rosecchi E. 1997. Fish and fisheries of the Prespa lakes, Hydrobiologia 351: 107-125, 1997.

4. Freyhof J., Brooks E. 2011. European Red List of Freshwater Fishes. Luxembourg: Publications Office of the European Union, 70 pp.

5. Freyhof J. 2012. Threatened freshwater fishes and molluscs of the Balkan, potential impact of hydropower projects. Berlin, Germany: ECA Watch Austria and EuroNatur, $86 \mathrm{pp}$.

6. Gashi A., Shabani E., Grapci-Kotori L., Bislimi K., Maxhuni Q., Ibrahimi H. 2016. Contribution to the knowledge of fish fauna of Kosovo with a special note on some invasive species, Turk J Zool. 40: 64-72.

7. Grapci Kotori L., Zhushi Etemi F., Sahiti H., Gashi A., Škrijelj R., Ibrahimi H. (2010): The ichthyofauna of Drini i Bardhë River (Kosovo). Croat J. Fish. 68: 149-158.

8. Grant, G.C., Schwartz Y. and Weisberg:S. 2004. Trends in abundance and mean size of fish captured in gill nets from Minnesota lakes, 19 83-1997. N Am. J. Fish. Manage., 24, 417-428.

9. Jackson, D.A., Peres-Neto, P.R. and Olden, J.D., 2001. What controls who is where in freshwater fish communities-the roles of biotic,abiotic, and spatial factors, Canadian Journal of Fisheries and Aquatic Sciences,58, 157-170.

10. Jensen J.W. 1986. Gillnet selectivity and efficiency of alternative combinations of mesh sizes for some freshwater fish. J. Fish. Biol., 28, 637-646. 
11. Kadye W.T., Moyo N.A.G., Magadza C.H.D. and Kativu S. 2008. Stream fish assemblages in relation to environmental factors on a Montane Plateau (Nyika Plateau, Malawi). Environmental Biology of Fishes, 83, 417-428

12. Kennard M.J., Arthington A.H., Pusey B.J., Harch B.D. 2005. Are alien fish a reliableindicator of river health, Freshwater Biol. 50, 174-193.

13. Kottelat M., Freyhof J. 2007. Handbook of European Freshwater Fishes. Cornol, Switzerland: Publications Kottelat.

14. Maxhuni Q., Škrijelj R., Grapci Kotori L. 2010. The influence of ecological factors on fish population dynamics in river Drenica. In: 4th International Scientific Conference BALWOIS 2010, Ohrid, Macedonia.

15. Minns C.K. and Hurley D.A. 1988. Effects of net length and set time on fish catches in gill nets. N. Am. J. Fish. Manage, 8, 216-223.

16. Musliu M., Bilalli A., Durmishi B., Ismaili M., Ibrahimi H. 2018. Water Quality Assessment of the Morava e Binçës River Based on the Physicochemical Parameters and Water Quality Index. J. Ecol. Engin., 19(6), 104-112.
17. Olin M., Malinen T. and Ruuhijarvi J. 2009. Gillnet catch in estimating the density and structure of fish community - Comparison of gillnet and trawl samples in a eutrophic lake. Fish. Res., 96, 88-94.

18. Rakaj N. 1995. Ihtiofauna e Shqipërisë (Ichthyofauna of Albania).Tirana, Albania: ShBLSh (in Albanian), $250 \mathrm{pp}$.

19. Simonović P. 2001. Ribe Srbije (Fish of Serbia). Belgrade, Serbia: NNK International (in Serbian), $170 \mathrm{pp}$.

20. Uzunova E., Velkov B., Studenkov S., Georgieva M., Nikolova M., Pehlivanov L., Parvanov D. 2007. Growth, age and size structure of the introduced pumpkinseed (Lepomis gibbosus L.) population from small ponds along the Vit River (Bulgaria). Bulg.J Agric.Sci. 4: 227-234.

21. Uzunova E., Zlatanova S. 2007. A review of the fish introductions in Bulgarian freshwaters. Acta Ichthyol. Piscat. 37(1), 55-61.

22. Vuković T., Ivanović B. 1971. Slatkovodne ribe Jugoslavije. Sarajevo, Bosnia and Hercegovina: Zemaljski muzej BiH Posebno izdanje (in SerboCroatian), 135 pp. 